Гула Олена Ігорівна аспірантка Міжрегіональної Академії управління персоналом, вул. Фрометівська, 2, м. Київ, 03039, тел.: (091) 303-79-77, https://orcid.org/0000-0002-6950-1087

\title{
СИСТЕМАТИЗАЦІЯ НАУКОВИХ ПІДХОДІВ ДО ВИЗНАЧЕННЯ КАДРОВОЇ БЕЗПЕКИ В СИСТЕМІ ПУБЛІЧНОГО УПРАВЛІННЯ
}

Анотація. У статті систематизовані підходи до поняття «кадрова безпека». 3'ясовано, що поняття кадрової безпеки аналізують вчені-економісти разом 3 тим мало приділено увагу кадровій безпеці в системі публічного управління. Обгрунтовано, що кадрова безпека в системі публічного управління - це сукупність механізмів,інструментів методів, спрямованих на мінімізацію або ліквідацію загроз та небезпек в системі кадрової політики. Кадрова безпека системи публічного управління є основою національної безпеки України. На нашу думку, якість кадрового потенціалу будь-якої сфери публічного управління впливає на державно-управлінські рішення, які приймаються у цій сфері публічного управління, а тому впливають і на саму безпеку. Без кадрів неможливо уявити будь-яке рішення, формування та реалізацію нормативно-правових актів України. Тому, саме кадрова безпека $\epsilon$ основою національної безпеки. До складових кадрової безпеки системи публічного управління відносяться: персонал; основні загрози (зовнішні та внутрішні); механізми забезпечення кадрової безпеки (відбір кадрів; мотивація; підготовка та підвищення кваліфікації; адаптація; кар'єрне зростання тощо); методи забезпечення кадрової безпеки (соціально-економічні; психологічні; адміністративні; організаційні; дисциплінарні; інформаційні); суб‘єкти забезпечення кадрової безпеки

До основних принципів кадрової безпеки в системі публічного управління слід віднести: системність; терміновість; надійність; законність; економічність; комунікативність; відкритість та приватність; професіоналізм; незалежність.

Обгрунтовано, що кадрова безпека в системі публічного управління реалізує ряд функцій у тому числі: організаційну - планування потреб і джерел комплектування персоналу; соціально-економічну - забезпечення комплексу умов i факторів, спрямованих на раціональне закріплення й використання персоналу; відтворювальну - забезпечення розвитку персоналу; комунікаційну - $\epsilon$ основою забезпечення діяльності пубічлного управління; формування системи розвитку персоналу 3 урахуванням вимог сучасного публічного управління; 
формування системи національної безпеки.

Ключові слова: публічне управління, кадрова безпека, кадрова політика, кадрова безпека в системі публічного управління, принципи кадрової безпеки.

Gula Olena Ihorivna Postgraduate student of the Interregional Academy of Personnel Management, Frometivska St., 2, Kyiv, 03039, tel.: (091) 303-79-77, https://orcid.org/0000-0002-6950-1087

\section{SYSTEMATIZATION OF SCIENTIFIC APPROACHES TO THE DEFINITION OF PERSONNEL SECURITY IN THE SYSTEM OF PUBLIC ADMINISTRATION}

Abstract. The article systematizes the approaches to the concept of "personnel security". The author found that the concept of personnel security is analyzed by economists, however, little attention is paid to personnel security in the system of public administration. The article substantiates that personnel security in the system of public administration is a set of mechanisms, tools and methods aimed at minimizing or eliminating threats and dangers in the system of personnel policy. Personnel security of the public administration system is the basis of national security of Ukraine. In our opinion, the quality of human resources in any area of public administration affects public administration decisions made in this area of public administration, and therefore affect security itself. Without personnel, it is impossible to imagine any decision, formation and implementation of regulations of Ukraine. Therefore, personnel security is the basis of national security. The components of personnel security of the public administration system include: staff; main threats (external and internal); mechanisms for ensuring personnel security (personnel selection; motivation; training and advanced training; adaptation; career growth, etc.); methods of ensuring personnel security (socioeconomic; psychological; administrative; organizational; disciplinary; information); personnel security entities.

The main principles of personnel security in the system of public administration should include: systematic; urgency; reliability; legality; economy; communicativeness; openness and privacy; professionalism; independence.

Personnel security in the system of public administration implements a number of functions, including: organizational - planning the needs and sources of staffing; socioeconomic - providing a set of conditions and factors aimed at the rational consolidation and use of personnel; reproductive - ensuring staff development; communication - is the basis for ensuring the activities of public administration; formation of a system of personnel development taking into account the requirements of modern public administration; formation of the national security system. 
Keywords: public administration, personnel security, personnel policy, personnel security in the system of public administration, principles of personnel security.

Постановка проблеми. Кадри відіграють важливу роль в системі публічного управління. Від їх якості, професіоналізму, оновлення та розвитку залежить якість всієї системи публічного управління, якість проведення реформування, якість та ефективність нормативно-правових рішень та державно-управлінських рішень.

Тому тема щодо забезпечення кадрової безпеки в системі публічного управління є важлива та актуальна.

Кадрова безпека - це основа забезпечення сучасного суспільства професійними кадрами, постійне оновлення кадрового потенціалу, розвиток та модернізація кадрів.

Аналіз останніх публікацій. Кадрова безпека, система формування кадрової безпеки часто розглядається науковцями як частина економічної безпеки підприємства та визначається з урахуванням економічних категорій. Хоча кадрова безпека є основою національної безпеки України.

Понятійно-категоріальний апарат кадрової безпеки, у тому числі кадрової безпеки в системі публічного управління аналізують Б. Городницький, Є. Горовіца, та науковців Л. Балабанов, О. Бандурко, Т. Васильців, В. Данюк, Ф. Свдокімов, О. Кириченко, Г. Козаченко, І. Мігус, Л. Миронов, В. Мутіян, В. Панченко, О. Пархоменко-Куцевіл, В. Петюх, С. Цимбалюк, та ін.

Так, О. Пархоменко-Куцевіл здійснила спробу систематизувати наукові підходи до кадрової безпеки державному управлінні [1].

Разом $з$ тим, відсутні системі підходи до визначення ролі кадрової безпеки в системі національної безпеки.

Метою дослідження є систематизація наукових підходів до визначення кадрової безпеки в системі публічного управління.

Виклад основного матеріалу. Кадрову безпеку в системі публічного управління можна розглядати у вузькому та широкому змістах. У вузькому змісті - це захист персоналу, забезпечення його розвитку, самореалізації, самовдосконалення. У широкому змісті - це сукупність методів, механізмів, прийомів, які забезпечують захищеність самої системи публічного управління від загроз непрофесіоналізму, деструктивного професіоналізму, збільшення кількості клановиків, осіб, які мають певні особисті зв'язки та ін. [1].

Кадрова безпека - це:

- процес запобігання негативним впливам на економічну безпеку підприємства за рахунок ризиків і загроз, пов'язаних із персоналом, його інтелектуальним потенціалом і трудовими відносинами у цілому [2];

- правове та інформаційне забезпечення процесу управління персоналом: вирішення правових питань трудових відносин, підготовка нормативних 
документів, що їх регулюють, забезпечення необхідною інформацією всіх підрозділів управління персоналом [3];

- процес запобігання негативним діям на безпеку підприємства за рахунок усунення ризиків та загроз, пов’язаних 3 інтелектуальним потенціалом та трудовими відносинами у цілому [4];

- беззбитковістю трудових відносин підприємства, метою якої є досягнення максимальної стабільності функціонування фірми, а також створення основи i перспективи росту для виконання іï основних завдан[5];

- генеральний напрям кадрової роботи, сукупність принципів, методів, форм організаційного механізму 3 опрацювання цілей, завдань, спрямованих на збереження, зміцнення й розвиток кадрового потенціалу, на створення відповідального і високопродуктивного згуртованого колективу, здатного вчасно реагувати на постійно мінливі вимоги ринку з урахуванням стратегії розвитку організації [6];

- забезпеченість підприємства кадровими ресурсами, формування ефективної системи управління персоналом та комунікативної політики. Інтелектуальний складник не може існувати поза межами кадрової безпеки, оскільки становить іiі частину [7];

- сукупність соціально-економічних, управлінських, соціальних та психологічних процесів, скерованих на убезпечення діяльності підприємства від загроз, зумовлених людським чинником [8];

- складова системи економічної безпеки підприємства, метою якої є ефективне економічне функціонування підприємства, повинна розглядатись через свою економічну сутність, виходити зі створення доданої вартості, додаткових цінностей, розглядатись у ланцюгу створення цінності, а також базуватись на процесному підході, бути інтегрованою у систему управління персоналом за рахунок мінімізації ризиків та попередження загроз, які пов’язані 3 ним та максимізацією його корпоративної соціально-економічної ефективності [9].

Таким чином, кадрова безпека в системі публічного управління - це сукупність механізмів,інструментів методів, спрямованих на мінімізацію або ліквідацію загроз та небезпек в системі кадрової політики.

До основних складових кадрової безпеки системи публічного управління відносяться: персонал; основні загрози (зовнішні та внутрішні); механізми забезпечення кадрової безпеки (відбір кадрів; мотивація; підготовка та підвищення кваліфікації; адаптація; кар'єрне зростання тощо); методи забезпечення кадрової безпеки (соціально-економічні; психологічні; адміністративні; організаційні; дисциплінарні; інформаційні); суб‘єкти забезпечення кадрової безпеки [1; 5].

Кадрова безпека є основою національної безпеки та ії фундаментом (рис.1). 


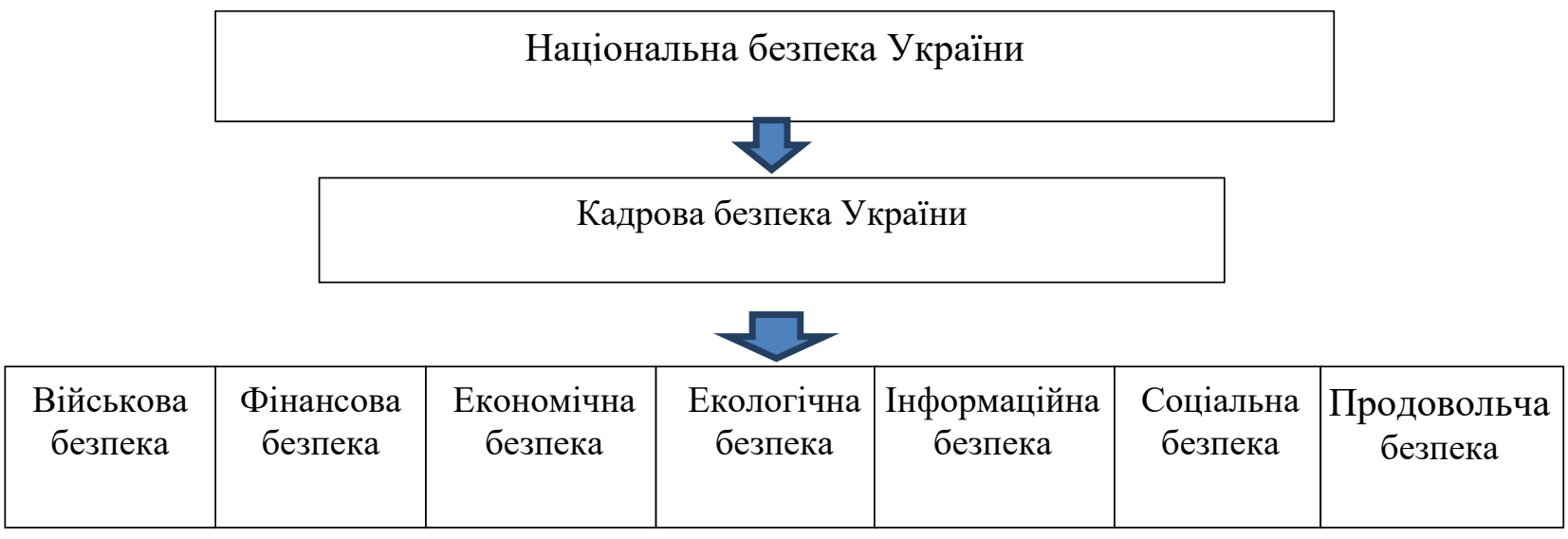

Рис. 1. Місие кадрової безпеки у структурі системи національної безпеки України.

На нашу думку, якість кадрового потенціалу будь-якої сфери публічного управління впливає на державно-управлінські рішення, які приймаються у цій сфері публічного управління, а тому впливають і на саму безпеку. Без кадрів неможливо уявити будь-яке рішення, формування та реалізацію нормативноправових актів України. Тому, саме кадрова безпека $є$ основою національної безпеки.

До основних принципів кадрової безпеки в системі публічного управління слід віднести:

1. Системність. Принцип системності означає, що в системі публічного управління повинна функціонувати система кадрової безпеки, за якої буде зберігатися режим захищеності для всіх складових публічного управління: система закладів, організаційну структуру, персонал, інформаційну складову, фінансову складову тощо. Таким чином, система безпеки повинна бути всебічно задовільною для того, щоб гарантувати захист публічного управління як зсередини, так і за його межами.

2. Терміновість. Принцип терміновості передбачає, що система кадрової безпеки вимагає такої побудови, за якої вона могла б розрізняти на початкових етапах всілякі аномальні відхилення в процесі функціонування публічного управління, брати участь в усуненні їх негативного впливу i, як наслідок, заподіяння шкоди.

3. Надійність. Принцип надійності передбачає, що система кадрової безпеки повинна грунтуватися на тому, щоб постійно забезпечувати захист інтересів системи публічного управління в сучасних глобалізаційних умовах розвитку світового суспільства.

4. Законність. Усі вжиті заходи щодо забезпечення кадрової безпеки повинні спиратися на чинне законодавство та нормативно-правові документи України. 
5. Економічність. Принцип економічності передбачає раціональний розподіл витрат на забезпечення кадрової безпеки таким чином, щоб обсяг витрат був економічно раціональним і не виходив за межі рівня економічного сенсу його використання.

6. Комунікативність. Для збереження режиму захищеності системи в інтересах кадрової безпеки варто, щоб зусилля всіх осіб, які іï забезпечують, були взаємопов’язаними. Тобто всі суб'єкти цього процесу повинні взаємодіяти один 3 одним, точно знати та виконувати свої обов'язки і повноваження.

7. Відкритість та приватність. Деякі способи, методи і засоби забезпечення кадрової безпеки повинні бути негласними, з якими може бути ознайомлене лише тісне коло фахівців, що працюють 3 конфіденційною інформацією і системі публічного управління. Такі заходи можуть зробити кардинальний вплив на боротьбу з внутрішніми і зовнішніми загрозами, вчасно запобігати негативним чинникам, які можуть призвести до дестабілізації господарської діяльності підприємства. Проте, сукупність базових заходів повинна бути відома всім службовцям та громадянам України [10].

8. Професіоналізм. Передбачає, що в системі публічного управління працюють лише професійні державні службовців та інші фахівці.

9. Незалежність, яка передбачає, що система кадрової безпеки незалежно від політичних впливів та на неї не впливають політичні пріоритети провладних партій, посадових осіб.

Кадрова безпека в системі публічного управління реалізує ряд функцій у тому числі:

- організаційну - планування потреб і джерел комплектування персоналу;

- соціально-економічну - забезпечення комплексу умов i факторів, спрямованих на раціональне закріплення й використання персоналу;

- відтворювальну - забезпечення розвитку персоналу [8];

- комунікаційну - є основою забезпечення діяльності публічного управління;

- формування системи розвитку персоналу з урахуванням вимог сучасного публічного управління;

- формування системи національної безпеки.

Висновки. У статті систематизовані підходи до поняття «кадрова безпека». 3'ясовано, що поняття кадрової безпеки аналізують вчені-економісти разом з тим мало приділено увагу кадровій безпеці в системі публічного управління. Обгрунтовано, що кадрова безпека в системі публічного управління - це сукупність механізмів,інструментів методів, спрямованих на мінімізацію або ліквідацію загроз та небезпек в системі кадрової політики. До основних принципів кадрової безпеки в системі публічного управління слід віднести: 
системність; терміновість; надійність; законність; економічність; комунікативність; відкритість та приватність; професіоналізм; незалежність.

\section{Лimepamypa:}

1. Пархоменко-Куцевіл О.I. Кадрова безпека в системі державного управління України: теоретичні засади. Ефективність державного управління : зб. наук. пр. 2013. Вип. 37. С. 13-20.

2. Панченко В. А. Місце кадрової безпеки в системі економічної безпеки підприємств. Науковий вісник Уэсгородського національного університету. 2018. Випуск 21. Частина 2. С. 53-60.

3. Проблеми управління економічною безпекою суб'єктів господарювання: монографія / О.А. Кириченко, М.П. Денисенко, В.С. Сідак та ін. К.: Університет економіки та права «КРОК», 2010. 412 c.

4. Система економічної безпеки: держава, регіон, підприємство: монографія: у 3-х т. Т. 1 / О.М. Ляшенко, Ю.С. Погорєлов, В.Л. Безбожний та ін.; за заг. ред. Г.В. Козаченко. Луганськ: Елтон - 2, 2010. $282 \mathrm{c}$.

5. Швець Н. Методи виявлення і збереження кадрової безпеки, або Як перемогти зловживання персоналу. Персонал. 2006. № 5. С 19-25.

6. Кибанов А.Я. Управление персоналом организации. М.: ИНФРА-М, 2002. 638 с.

7. Мігус І. П. Створення системи управління кадровою безпекою на підприємстві. Вчені записки Університету «КРОК». 2018. № 4 (52). С. 213-221.

8. Ляшенко А.Н., Криль Я.Н. Кадрова безпека у системі економічної безпеки підприємства. Економіка. Менеджмент. Підприємництво: Збірник наукових праць Східноукраїнського національного ун-ту ім. Володимира Даля. 2013. №25. С. 274-279.

9. Поскрипко Ю.А. Категорийный анализ кадровой безопасности. Економіка $i$ Фінанси. 2014. № 1. C. 7-13.

10. Кавтиш О.П. Системна природа кадрової безпеки підприємства. Економічний вісник НТУУ «КПI». 2015. № 2. С.181-189.

\section{References:}

1. Parkhomenko-Kutsevil O.I. (2013) Kadrova bezpeka v systemi derzhavnoho upravlinnia Ukrainy: teoretychni zasady [Personnel security in the system of public administration of Ukraine: theoretical principles]. Efektyvnist derzhavnoho upravlinnia : zb. nauk. pr. - Efficiency of public administration: coll. Science. etc., Vyp. 37. [in Ukrainian].

2. Panchenko V. A. (2018) Mistse kadrovoi bezpeky v systemi ekonomichnoi bezpeky pidpryiemstv[The place of personnel security in the system of economic security of enterprises]. Naukovyi visnyk Uzhhorodskoho natsionalnoho universytetu - Scientific Bulletin of Uzhhorod National University, Vypusk 21, Chastyna 2. [in Ukrainian]

3. Kyrychenko O.A., Denysenko M.P.\& Sidak V.S. (2010) Problemy upravlinnia ekonomichnoiu bezpekoiu subiektiv hospodariuvannia: monohrafiia [Problems of economic security management of business entities: monograph], K.: Universytet ekonomiky ta prava «KROK». [in Ukrainian]

4. Liashenko O.M., Pohorielov Yu.S. \& Bezbozhnyi V.L. (2010) Systema ekonomichnoi bezpeky: derzhava, rehion, pidpryiemstvo: monohrafiia [System of economic security: state, region, enterprise: monograph]: u 3-kh t. T. 1. Luhansk: Elton - 2. [in Ukrainian]

5. Shvets N. (2006) Metody vyiavlennia i zberezhennia kadrovoi bezpeky, abo Yak peremohty 
zlovzhyvannia personalu [Methods of identifying and maintaining personnel security, or How to overcome the abuse of personnel]. Personal-Personnel, (5). [in Ukrainian]

6. Kybanov A.Ia. (2002) Upravlenye personalom orhanyzatsyy [Personnel management of the organization], M.: YNFRA-M. [in Ukrainian]

7. Mihus I. P. (2018) Stvorennia systemy upravlinnia kadrovoiu bezpekoiu na pidpryiemstvi [Creating a personnel security management system at the enterprise]. Vcheni zapysky Universytetu «KROK»-Scientific notes of KROK University, (4 (52). [in Ukrainian]

8. Liashenko A.N. \& Kryl Ya.N. (2013) Kadrova bezpeka u systemi ekonomichnoi bezpeky pidpryiemstva [Personnel security in the system of economic security of the enterprise]. Ekonomika. Menedzhment. Pidpryiemnytstvo: Zbirnyk naukovykh prats Skhidnoukrainskoho natsionalnoho un-tu im. Volodymyra Dalia - Economy. Management. Entrepreneurship: Collection of scientific works of the East Ukrainian National University named after Vladimir Dahl, (25). [in Ukrainian]

9. Poskrypko Yu.A. (2014) Katehoryiny analyz kadrovoi bezopasnosty [Categorical analysis of personnel security]. Ekonomika i Finansy - Economics and Finance, (1). [in Russian].

10. Kavtysh O.P. (2015) Systemna pryroda kadrovoi bezpeky pidpryiemstva [The systemic nature of personnel security of the enterprise]. Ekonomichnyi visnyk NTUU «KPI»- Economic Bulletin of NTUU "KPI", (2). 